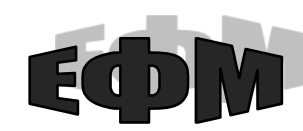

http://efm.vsau.org/

MULYK Tetiana - Candidate of Economic Sciences, Associate Professor, Head of the Analysis and Statistics Department, Vinnytsia National Agrarian University (21008, Vinnytsia, 13 Soniachna Str., e-mail: mulyk_t_o@ukr.net).

TOMCHUK Olena - Candidate of Economic Sciences, Associate Professor, Associate Professor of the Analysis and Statistics Department (21008, Vinnytsia, 13 Soniachna Str., e-mail: olenatomchuk@ukr.net).

FEDORYSHYNA Lidiia - Candidate of Historical Sciences, Associate Professor, Associate Professor of the Analysis and Statistics Department (21037, Vinnytsia, 41 Keletska Str., e-mail: fedorishina@i.ua).

МУЛЫК Татьяна Алексеевна - кандидат экономических наук, доцент, заведующая кафедрой анализа и статистики, Винницкий национальный аграрный университет (21008, г. Винница, ул. Солнечная, 13, e-mail: mulyk_t_o@ukr.net).

ТОМЧУК Елена Феликсовна - кандидат экономических наук, доцент, доцент кафедры анализа и статистики (21008, г. Винница, ул. Солнечная, 13, e-mail: olenatomchuk@ukr.net).

ФЕДОРИШИНА Лідія Іванівна - кандидат исторических наук, доцент, доцент кафедры анализа и статистики (21037, г. Винница, ул. Келецкая, 41, e-mail: fedorishina@i.ua).

УАК 657.6:349.233:061

ОРГАНІЗАЦІЯ КОНТРОЛЮ ЗА АІЯЛЬНІСТЮ МАТЕРІАЛЬНО ВІДПОВІДАЛЬНИХ ОСІБ В НАУКОВИХ УСТАНОВАХ ${ }^{\odot}$
К.В. КОПИЛОВА, доктор сільськогосподарських наук, стариий науковий співробітник, заступник директора з наукової та інноваційної роботи, Інститут продовольчих ресурсів НА $\boldsymbol{A Н ~ У к р а і ̈ н и ~}$ (м. Kü̈в), Я.I. МУЛИК, кандидат економічних наук, старший викладач кафедри аудиту та держсавного контролю, Вінницький національний аграрний університет (м. Вінниця)

Досліджено методичний інструментарій організації контролю за діяльністю матеріально-відповідальних осіб в наукових установах. Розглянуто функціонування Інституту продовольчих ресурсів НААН Украйни як співзасновника Навчальнонауково-виробничого комплексу “Всеукрайнський науково-навчальний консориіум”. Розглянуто Методичні рекомендації 3 організації внутрішнього контролю

(ㄷ) к.в. копиловА, Я. І. мулик, 2019 


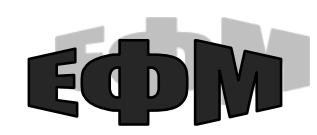

http://efm.vsau.org/

розпорядниками бюджетних коштів у своїх закладах та у підвідомчих бюджетних установах. Розглянуто поняття терміну “відповідальність” та охарактеризовано різні види юридичної відповідальності. Досліджено наукові підходи до трактування терміну “матеріальна відповідальність". Розглянуто види матеріальної відповідальності, перелік підстав для притягнення працівника до матеріальної відповідальності. Досліджено порядок укладення договору про повну матеріальну відповідальність та відшкодування шкоди. Визначено основні напрями вдосконалення контролю за діяльністю матеріально-відповідальних осіб в наукових установах, щзо буде сприяти поліпшенню інформащійних потреб власників та керівників та прийняттю ефективних управлінських рішень.

Ключові слова: контроль, внутрішній контроль, матеріально-відповідальна особа, наукова установа, Інститут продовольчих ресурсів НААН України, ННВК “Всеукраїнський науково-навчальний консорціум”.

Табл. 5. Рис. 1. Літ. 12.

\title{
THE ORGANIZATION OF CONTROL OVER THE ACTIVITIES OF MATERIALLY RESPONSIBLE PERSONS IN THE SCIENTIFIC INSTITUTIONS
}

\author{
KOPYLOVA Ekaterina \\ Doctor of Agricultural Sciences, \\ Senior Researcher \\ Deputy Director of the Scientific and Innovative Work \\ of the Institute of Food Resources of the NASU
}

(Kiev)

MULYK Yaroslavna, Candidate of Economic Sciences, Senior Lecturer of the Audit and State Control Department, Vinnytsia National Agrarian University (Vinnytsia)

The methodical tools of the organization of control over the activities of materially responsible persons in the scientific institutions are researched. The functioning of the Institute of Food Resources of the National Academy of Sciences of Ukraine as a co-founder of the Educational, Scientific and Production Complex of "All-Ukrainian Scientific and Training Consortium" is considered. The methodical recommendations for organizing the internal control of budget funds managers in their institutions and subordinated budget institutions are considered. The concept of the term "responsibility" is considered and the different types of legal responsibility are described. The scientific approaches to the interpretation of the term "material responsibility" are studied. The types of material responsibility, the list of grounds for bringing the employee to material responsibility are considered. The procedure of signing the contract on full material responsibility and indemnity are investigated. The main directions of improvement of control over the activity of materially responsible persons in the scientific institutions are determined, which will help to improve the information needs of owners and managers and the adoption of effective managerial decisions.

Key words: control, internal control, materially responsible person, scientific institution, Institute of Food Resources of the National Academy of Sciences of Ukraine, All-Ukrainian Scientific and Training Consortium.

Tabl. 5. Fig. 1. Lit. 12. 


\title{
ОРГАНИЗАЦИЯ КОНТРОЛЯ ЗА ДЕЯТЕЛЬНОСТЬЮ МАТЕРИАЛЬНО- ОТВЕТСТВЕННЫХ ЛИЦ В НАУЧНЫХ УЧРЕЖДЕНИЯХ
}

\author{
КОПЫЛОВА Екатерина Вячеславовна, \\ доктор сельскохозяйственных наук, \\ стариий научный сотрудник, \\ заместитель директора по научной и инновационной работе \\ Институт продовольственных ресурсов НААН Украины \\ (2. Киев)

МУЛЫК Ярославна Игоревна,
кандидат экономических наук,
стариий преподаватель кафедры
аудита и государственного контроля,
Винницкий национальный аграрный университет
(2. Винница)

Исследован методический инструментарий организащии контроля за деятельностью материально-ответственных лич в научных учреждениях. Рассмотено функционирование Института продовольственных ресурсов НААН Украинь как соучредителя учебно-научно-производственного комплекса - "Всеукраинский научно-учебный консорчичм". Рассмотрены Методические рекомендации организачии внутреннего контроля распорядителями бюджетных средств в своих заведениях и в подведомственных бюджетных учреждениях. Рассмотрено понятие термина "ответственность" и охарактеризованы разные виды юридической ответственности. Исследованы научные подходы к трактовке термина "материальная ответственность". Рассмотрены виды материальной ответственности, перечень оснований для привлечения работника к материальной ответственности. Исследован порядок заключения договора о полной материальной ответственности и возмещении вреда. Определены основные направления совершенствования контроля за деятельностью материальноответственных лич в научных учреждениях, что будет способствовать улучшению информационных потребностей собственников и руководителей и принятию эффективных управленческих решений.

Ключевые слова: контроль, внутренний контроль, материальноответственное лицо, научное учреждение, Институт продовольственных ресурсов НААН Украины, ННВК "Всеукраинский научно-учебный консорциум".

Табл. 5. Рис. 1. Лит. 12.

Постановка проблеми. В сучасних умовах розвитку економіки країни, важлива роль відводиться науковим установам. Саме вони є основними виробниками інновацій та прогресу суспільства. Враховуючи особливості їх діяльності та сучасні умови господарювання, контроль займає особливе місце в здійснені заходів, які направлені на збереження майна власника та дозволяє викрити ймовірні відхилення в діяльності та вжити заходів щодо їх усунення.

В системі контролю важлива роль відводиться організації контролю за діяльністю матеріально-відповідальних осіб. Даний вид контролю є досить гострою та дискусійною проблемою в наукових колах не лише України, а й ряду зарубіжних 


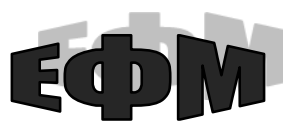

http://efm.vsau.org/

країн. Розвиток відносин у сфері праці, необхідність адаптації трудового законодавства до норм Європейського Союзу визначають пріоритетність досліджень у сфері трудових відносин, де важливою складовою виступає матеріальна відповідальність. Тому оцінка діяльності матеріально-відповідальних осіб в наукових установах за трудовим законодавством України та контроль за даним процесом $є$ актуальним та необхідним в сучасних умовах господарювання.

Аналіз останніх досліджень та публікацій. Питання організації науководослідницької діяльності у вищій школі та наукових закладах досліджували вчені Я.М. Гадзало, Г. М. Калетнік, І.В. Гунько, М.В. Роїк, М. П. Сичевський, М. В. Гладій, П.Т. Саблук, В.В. Адамчук, В.В. Снітинський, Ю.Ф.Мельник, В.Ф. Петриченко, Ю.О. Лупенко та інші.

Організацію діяльності Всеукраїнського навчально-наукового консорціуму в Україні, який за своєю сутністю виступає інноваційним проектом в науці та освіті, розглядали вчені Г. М. Калетнік [1], І.В. Гончарук, І.В. Гунько [1], Е. А. Кірєєва [1], М.В. Роїк.

Питання організації контролю, та зокрема, контролю за діяльністю матеріально-відповідальних осіб, види відповідальності працівників та роботодавців як суб'єктів трудових правовідносин, вдосконалення контролю були предметом наукових вивчень Л. В. Гуцаленко [2], М. І. Коцупатрого [2], У.О. Марчук [2], Н. Г. Здирко, В.Ю.Фабіянської, О.А. Сироватської, О.М. Ярошенко, М. М. Левенець [3], М.А. Мацько [4], О.С. Костюченко [5] та інших вчених. Втім, не дивлячись на грунтовні дослідження означених науковців, даний вид контролю залишається актуальним. Досьогодні залишається дискусійною проблема щодо поняття відповідальності, $є$ необхідність оцінки та дослідження відповідальності в трудовому законодавстві, iї поліпшення та вдосконалення, і зокрема, особливостей організації контролю за діяльністю матеріально-відповідальних осіб в наукових установах. Вище викладене свідчить про актуальність даного дослідження.

Формулювання цілей статті. Метою статті є дослідження стану організації контролю за діяльністю матеріально-відповідальних осіб в наукових установах та розробка заходів щодо його поліпшення.

Виклад основного матеріалу дослідження. Наукові установи відіграють важливу роль в інноваційній спрямованості України та $є$ визначальним чинником прогресу суспільства, поліпшення добробуту громадян.

За статистичними даними (табл.1) в Україні в сфері наукових досліджень та розробок в 2017 р. нараховувалось 4063 суб'єкти господарювання, що складає лише 0,23 \% від загальної кількості суб'єктів господарювання, при цьому спостерігається тенденція до зменшення кількості осіб в цій сфері та їх питомої ваги. Так, наприклад, в 2013 році їх налічувалось - 4361, а їх питома вага становила 0,25\%.

Дані статистичних органів, свідчать також про незначний обсяг виробленої продукції (товарів, послуг) суб'єктів господарювання в сфері наукових досліджень та розробок (табл.2). Так, в 2017 році даний обсяг складає 13343,7 млн.грн. або ж 0,25 \% в загальному обсязі виробленої продукції (товарів, послуг) суб'єктів господарювання в сфері наукових досліджень та розробок. Результати аналізу свідчать про коливання обсягів виробленої продукції в галузі наукових досліджень в розрізі років, натомість питома вага даної продукції до 2016 р. зростала, тоді як в 2017 р. стала меншою. 


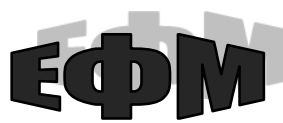

http://efm.vsau.org/

Таблиия 1

Кількість суб'сктів господарювання

в сфері наукових досліджень та розробок у 2013-2017 роках

\begin{tabular}{|c|c|c|c|c|c|c|}
\hline \multirow{4}{*}{ Роки } & \multicolumn{6}{|c|}{ Кількість суб’сктів господарювання } \\
\hline & \multirow{3}{*}{ усього } & \multirow{3}{*}{$\begin{array}{c}\text { з них у } \\
\text { фізичних осіб- } \\
\text { підприємців }\end{array}$} & \multicolumn{4}{|c|}{$\begin{array}{c}\text { в тому числі суб'сктів господарювання в сфері } \\
\text { наукових досліджень та розробок }\end{array}$} \\
\hline & & & \multicolumn{2}{|c|}{ усього } & \multicolumn{2}{|c|}{$\begin{array}{l}\text { з них у фізичних осіб- } \\
\text { підприсмців }\end{array}$} \\
\hline & & & K-Tb & $\%$ & K-Tb & $\%$ \\
\hline 2013 & 1722251 & 1328743 & 4361 & 0,25 & 1327 & 0,10 \\
\hline 2014 & 1932325 & 1591160 & 4354 & 0,23 & 1775 & 0,11 \\
\hline 2015 & 1974439 & 1630878 & 4392 & 0,22 & 1931 & 0,12 \\
\hline 2016 & 1865631 & 1559161 & 3899 & 0,21 & 2033 & 0,13 \\
\hline 2017 & 1805144 & 1466803 & 4063 & 0,23 & 2062 & 0,14 \\
\hline
\end{tabular}

Джерело: сформовано авторами на основі статистичних даних [6]

Загалом, попри значення та роль наукових установ у розвитку держави, представлений аналіз свідчить про незначну кількість суб' єктів господарювання в цій сфері та обсяг продукції (робіт, послуг), що вони виробляють.

Одним із представників наукових установ $є$ Інститут продовольчих ресурсів НААН України, який крім того виступає співзасновником Навчально-наукововиробничого комплексу “Всеукраїнський науково-навчальний консорціум” [1, с. 10].

Обсяг виробленої продукції (товарів, послуг) суб'єктів господарювання в сфері наукових досліджень та розробок у 2013-2017 роках, (млн.грн)

\begin{tabular}{|c|c|c|c|c|c|c|}
\hline \multirow{4}{*}{ Роки } & \multicolumn{6}{|c|}{ Обсяг виробленої продукції (товарів, послуг) суб'сктів господарювання } \\
\hline & \multirow{3}{*}{ усього } & \multirow{3}{*}{$\begin{array}{c}\text { з них у фізичних } \\
\text { осіб- } \\
\text { підприсмців }\end{array}$} & \multicolumn{4}{|c|}{$\begin{array}{c}\text { в тому числі суб'сктів господарювання в } \\
\text { сфері наукових досліджень та розробок }\end{array}$} \\
\hline & & & \multicolumn{2}{|c|}{ усього } & \multicolumn{2}{|c|}{$\begin{array}{c}\text { них у фізичних осіб- } \\
\text { підприсмців }\end{array}$} \\
\hline & & & сума & $\%$ & сума & $\%$ \\
\hline 2013 & 2593267,0 & 124476,8 & 9054,8 & 0,35 & 319,9 & 0,26 \\
\hline 2014 & 2885562,7 & 161591,5 & 8006,3 & 0,28 & 477,3 & 0,30 \\
\hline 2015 & 3449879,7 & 234591,8 & 10124,0 & 0,29 & 887,0 & 0,38 \\
\hline 2016 & 4217825,8 & 333208,2 & 18129,5 & 0,43 & 1146,5 & 0,34 \\
\hline 2017 & 5328975,4 & 456227,3 & 13343,7 & 0,25 & 1551,1 & 0,34 \\
\hline
\end{tabular}

Джерело: сформовано авторами на основі статистичних даних [6]

Він “ $є$ провідною установою 3 наукового забезпечення технічного та технологічного прогресу харчової та переробної промисловості України, а також розв `язання економічних проблем розвитку зазначених галузей. Діяльність наукової установи, створеної 2012 р. на базі Технологічного інституту молока та м яса шляхом розширення сфери його діяльності, полягає у проведенні досліджень, здійсненні та впровадженні наукових розробок у виробництво 3 метою раціонального використання сировинних ресурсів, підвищення ефективності виробництва, забезпечення належної якості та посилення конкурентоспроможності вітчизняної продукції в умовах формування ринкових відносин у м'ясопереробній, молокопереробній, цукровій, спиртовій, хлібобулочній, кондитерській та інших підгалузей харчової та переробної індустрії України" [7]. 
В діяльності Інституту продовольчих ресурсів НААН України та інших наукових установ, важливе місце відводиться контролю, адже в сучасних умовах вони можуть зазнавати різних збитків внаслідок неналежного здійснення договірних зобов'язань; виконання посадових обов'язків (розкрадання, втрата, пошкодження майна); недобросовісної конкуренції; невиконання обставини непереборної сили тощо. Отримання збитків на практиці тягне за собою відповідальність різних осіб.

Згідно із Методичними рекомендаціями з організації внутрішнього контролю розпорядниками бюджетних коштів у своїх закладах та у підвідомчих бюджетних установах [8], які затверджені наказом МФУ № 995 від 14.09.2012 р. із змінами та доповненнями “основою внутрішнього контролю (фінансового управління i контролю) є відповідальність керівника за управління та розвиток установи в цілому (управлінська відповідальність та підзвітність), до основних завдань якого належить планування та організація діяльності, формування адекватної структури внутрішнього контролю, нагляд за здійсненням внутрішнього контролю та управління ризиками для досягнення впевненості в межах розумного в тому, що мета і цілі установи будуть досягнуті, а рішення, включаючи фінансові, виконуватимуться з урахуванням принципів законності, економічності, ефективності, результативності та прозорості”.

Як зазначають Гуцаленко Л. В., Коцупатрий М. М. та Марчук У.О. “Історична ретроспектива поняття "відповідальність" виявила що за змістом це покладений на когось або взятий на себе обов'язок відповідати за певну ділянку роботи, справу, за чиїсь дії, вчинки, слова. Ширше й більш узагальнено тлумачиться це поняття у “Філософському словнику”: “Відповідальність - категорія етики і права, що відображає особливе соціальне і морально-правове ставлення особистості до суспільства (людства в цілому), яке характеризується виконанням свого морального боргу й правових норм" [2, с. 116].

Немає єдиного визначення щодо сутності юридичної відповідальності. Вчені розглядають та обгрунтовують своє бачення щодо даного поняття. Проаналізувавши думки науковців 3 цього питання Костюченко О.С. резюмує "одні науковці стверджують, що юридична відповідальність $€$ застосуванням до порушника відповідної санкції за порушення правової норми та негативні наслідки для нього. Інші вважають, що юридична відповідальність являє собою правове явище, яке об'єкти візується й реалізується в межах особливого, охоронного правового відношення. При цьому єдність наукових підходів полягає в тому, що ніхто не заперечує того, що юридична відповідальність $є$ наслідком порушення нормативних приписів" [5, с. 82].

Розрізняють різні види юридичної відповідальності (рис.1). Серед них, важливе місце відводиться матеріальній відповідальності.

До матеріальної відповідальності може бути притягнена будь-яка особа, яка склала трудовий договір та нанесла шкоду науковій установі, під час виконання своїх службових обов'язків. Крім того до матеріальної відповідальності може також притягуватись роботодавець за неякісне виконання своїх обов'язків, в результаті чого завдана шкода працівникові. 


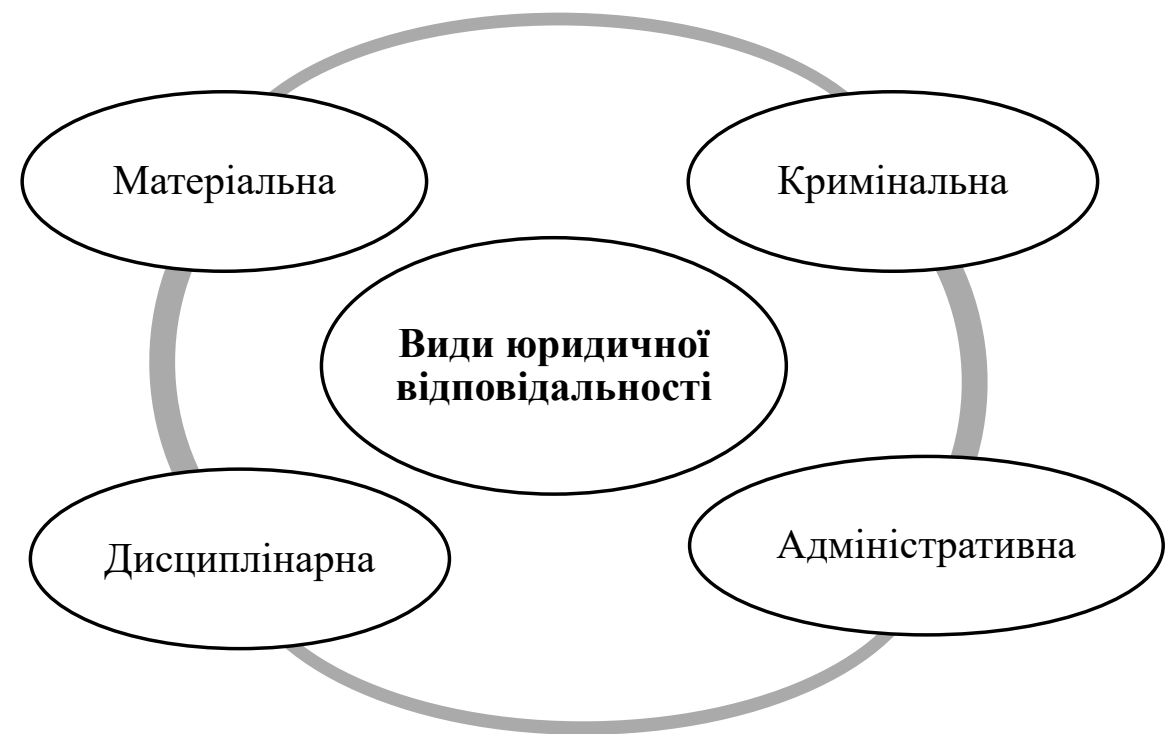

Рис. 1. Види юридичної відповідальності.

Джерело: побудовано авторами на основі [2, с.117]

Вчені, що трактують сутність матеріальної відповідальності (табл. 3) в основному підтверджують те, що матеріальна відповідальність тягне за собою відповідальність за неналежне виконання службових обов'язків.

\section{Визначення сутності поняття «матеріальна відповідальність»}

Таблиия 3

\begin{tabular}{|c|c|}
\hline Автор/джерело & Зміст матеріальної відповідальності \\
\hline $\begin{array}{c}\text { Гуцаленко Л.В., } \\
\text { Коцупатрий М.М., } \\
\text { Марчук У.О. } \\
\text { [2, с. 117] }\end{array}$ & $\begin{array}{l}\text { це добровільне чи примусове відшкодування стороною трудового } \\
\text { договору шкоди за збиток, завданий іншій стороні майновим або (i) } \\
\text { немайновим, протиправним, винним невиконанням або неналежним } \\
\text { виконанням своїх трудових обов'язків внаслідок дії чи бездіяльності, } \\
\text { в порядку і розмірі, визначеному законодавством }\end{array}$ \\
\hline $\begin{array}{l}\text { Левенець М.М. } \\
\text { [3, с.141] }\end{array}$ & $\begin{array}{l}\text { заподіяння фізичним або юридичним особам матеріальної чи } \\
\text { моральної шкоди незаконними рішеннями, діями чи бездіяльністю } \\
\text { під час здійснення своїх повноважень. }\end{array}$ \\
\hline $\begin{array}{l}\text { Мацько М.А. } \\
{[4, \text { c.243] }}\end{array}$ & $\begin{array}{l}\text { полягає в обов’язку відшкодувати заподіяну шкоду однієї із сторін } \\
\text { іншій стороні в порядку і розмірах, визначених трудових } \\
\text { законодавством. }\end{array}$ \\
\hline $\begin{array}{l}\text { Костюченко О.Є. } \\
{[5, \text { c.82] }}\end{array}$ & $\begin{array}{l}\text { порушення однією зі сторін трудового договору чи контракту своїх } \\
\text { обов'язків, внаслідок якого було заподіяно шкоду іншій стороні. }\end{array}$ \\
\hline $\begin{array}{l}\text { Мироненко В.П. } \\
{[9, \text { с.53] }}\end{array}$ & $\begin{array}{l}\text { становить собою обов'язок однієї сторони трудового договору - } \\
\text { працівника або власника (уповноваженого ним органу) відшкодувати } \\
\text { іншій стороні шкоду, заподіяну внаслідок винного, протиправного } \\
\text { невиконання або неналежного виконання трудових обов’язків у } \\
\text { встановленому законом розмірі й порядку. }\end{array}$ \\
\hline
\end{tabular}

Джерело: узагальнено авторами на основі літературних джерел [2-5, 9].

Загальні підстави та умови матеріальної відповідальності працівників визначені ст. 130 КЗПП, якою передбачено, що працівники несуть матеріальну відповідальність за шкоду, заподіяну підприємству, установі, організації внаслідок порушення покладених на них трудових обов'язків" [10]. 
Втім необхідно зазначити, що на працівників не може бути покладена відповідальність за шкоду, яка відноситься до категорії нормального виробничогосподарського ризику, а також за шкоду, заподіяну працівником, що перебував у стані крайньої необхідності. Відповідальність за не одержаний підприємством, установою, організацією прибуток може бути покладена лише на працівників, що є посадовими особами" [10].

На практиці передбачено перелік різних підстав для притягнення працівника до матеріальної відповідальності (табл. 4).

\section{$\begin{array}{ll}\text { Таблиця } 4 & \end{array}$}

Перелік підстав для притягнення працівника до матеріальної відповідальності

\begin{tabular}{|c|c|}
\hline Перелік підстав & 3міст підстави \\
\hline $\begin{array}{c}\text { Наявність прямої } \\
\text { дійсної шкоди }\end{array}$ & $\begin{array}{l}\text { розуміють втрату, погіршення або пониження цінності майна, } \\
\text { необхідність для підприємства, установи, організації зробити витрати на } \\
\text { відновлення, придбання майна або інших цінностей або зробити зайві } \\
\text { виплати. }\end{array}$ \\
\hline $\begin{array}{l}\text { Порушення } \\
\text { працівником або } \\
\text { власником } \\
\text { трудових } \\
\text { обов'язків } \\
\end{array}$ & $\begin{array}{l}\text { протиправною є поведінка працівника, який не виконує або неналежним } \\
\text { чином виконує обов'язки, передбачені законодавством, правилами } \\
\text { внутрішнього трудового розпорядку, посадовими інструкціям, } \\
\text { трудовим договором, наказами і розпорядженнями власника або } \\
\text { уповноваженого ним органу. }\end{array}$ \\
\hline $\begin{array}{l}\text { Причинний зв'язок } \\
\text { між порушенням } i \\
\text { шкодою }\end{array}$ & $\begin{array}{l}\text { відповідальність керівників підприємств, структурних підрозділів та їх } \\
\text { заступників наступає у випадках, коли майнова шкода виникла у зв'язку } \\
3 \text { неправильною постановкою обліку і зберігання грошових цінностей, } \\
\text { невжиттям необхідних заходів для запобігання простоям, випуску } \\
\text { недоброякісної продукції, розкраданню, знищенню і псуванню } \\
\text { матеріальних грошових цінностей }\end{array}$ \\
\hline $\begin{array}{c}\text { Наявність провини } \\
\text { прачівника }\end{array}$ & $\begin{array}{l}\text { представляє собою відношення працівника до заподіяної шкоди у формі } \\
\text { умислу чи необережності. При цьому матеріальна відповідальність у } \\
\text { трудовому праві, не може наступати без вини, при ії покладанні на } \\
\text { працівника, вина повинна бути обов'язково встановлена. }\end{array}$ \\
\hline
\end{tabular}

Джерело: сформовано авторами на основі [11, с.150]

Трудовим законодавством регламентуються різні види матеріальної відповідальності, в тому числі і для наукових установ: обмежена, повна та колективна (бригадна). Їх характеристика представлена в табл. 5.

\section{Види матеріальної відповідальності}

\begin{tabular}{|c|c|c|}
\hline $\begin{array}{c}\text { Види } \\
\text { відповідальності }\end{array}$ & $\begin{array}{c}\text { Суть } \\
\text { відповідальності }\end{array}$ & Особи, що притягуються до відповідальності \\
\hline 1 & 2 & 3 \\
\hline $\begin{array}{c}\text { Обмежена } \\
\text { матеріальна } \\
\text { відповідальність }\end{array}$ & $\begin{array}{c}\text { Відповідальність } \\
\text { у розмірі } \\
\text { заподіяної шкоди } \\
\text { в межах } \\
\text { середнього } \\
\text { місячного } \\
\text { заробітку }\end{array}$ & $\begin{array}{l}\text { працівники - за зіпсуття або знищення через недбалість } \\
\text { матеріалів, напівфабрикатів, виробів (продукції), в тому } \\
\text { числі при їх виготовленні, -у розмірі заподіяної з їх вини } \\
\text { шкоди, але не більше свого середнього місячного } \\
\text { заробітку. В такому ж розмірі працівники несуть } \\
\text { матеріальну відповідальність за зіпсуття або знищення } \\
\text { через недбалість інструментів, вимірювальних приладів, } \\
\text { спеціального одягу та інших предметів, виданих } \\
\text { підприємством, установою, організацією працівникові в } \\
\text { користування }\end{array}$ \\
\hline
\end{tabular}

Таблиия 5 
Продовження табл. 5

\begin{tabular}{|c|c|c|}
\hline 1 & 2 & 3 \\
\hline & & $\begin{array}{l}\text { керівники підприємств, установ, організацій та їх } \\
\text { заступники, а також керівники структурних } \\
\text { підрозділів на підприємствах, в установах, } \\
\text { організаціях та їх заступники - у розмірі заподіяної } 3 \\
\text { їх вини шкоди, але не більше свого середнього } \\
\text { місячного заробітку, якщо шкоду підприємству, } \\
\text { установі, організації заподіяно зайвими грошовими } \\
\text { виплатами працівникам, неправильною постановкою } \\
\text { обліку і зберігання матеріальних, грошових чи } \\
\text { культурних цінностей, невжиттям необхідних заходів } \\
\text { до запобігання простоям }\end{array}$ \\
\hline \multirow{8}{*}{$\begin{array}{c}\text { Повна } \\
\text { матеріальна } \\
\text { відповідальність }\end{array}$} & \multirow{8}{*}{$\begin{array}{l}\text { Відповідальність } \\
\text { у повному } \\
\text { розмірі за шкоду, } \\
\text { заподіяну з їхньої } \\
\text { вини } \\
\text { підприємству }\end{array}$} & $\begin{array}{l}\text { працівники } i \text { підприємство, що уклали письмовий } \\
\text { договір про повну матеріальну відповідальність за } \\
\text { незабезпечення цілості майна й інших цінностей, } \\
\text { переданих йому для зберігання або для інших цілей. }\end{array}$ \\
\hline & & $\begin{array}{l}\text { працівники, що одержали під звіт майно та інші } \\
\text { цінності за разовою довіреністю або за іншими } \\
\text { разовими документами. }\end{array}$ \\
\hline & & $\begin{array}{l}\text { прачівники, що завдали шкоди своїми діями, які } \\
\text { мають ознаки діянь, переслідуваних у кримінальному } \\
\text { порядку. }\end{array}$ \\
\hline & & $\begin{array}{l}\text { прачівники, що завдали шкоди підприємству, які } \\
\text { перебували в нетверезому стані. }\end{array}$ \\
\hline & & $\begin{array}{l}\text { працівники, що завдали шкоди недостачею, умисним } \\
\text { знищенням або умисним зіпсуванням матеріалів, } \\
\text { напівфабрикатів, виробів (продукції) тощо. }\end{array}$ \\
\hline & & $\begin{array}{l}\text { прачівники, що завдали шкоди підприємству при } \\
\text { виконанні трудових обов'язків }\end{array}$ \\
\hline & & $\begin{array}{l}\text { службова особа, винна в незаконному звільненні або } \\
\text { переведенні працівника на іншу роботу. }\end{array}$ \\
\hline & & $\begin{array}{l}\text { керівник підприємства, установи, організаиії винний } \\
\text { у несвоєчасній виплаті заробітної плати понад один } \\
\text { місяць, що призвело до виплати компенсацій, за } \\
\text { порушення строків ії виплати, і за умови, що } \\
\text { Державний бюджет України та місцеві бюджети, } \\
\text { юридичні особи державної форми власності не мають } \\
\text { заборгованості перед цим підприємством. }\end{array}$ \\
\hline $\begin{array}{c}\text { Колективна } \\
\text { матеріальна } \\
\text { відповідальність }\end{array}$ & $\begin{array}{l}\text { Відповідальність, } \\
\text { що виникає в разі } \\
\text { спільного } \\
\text { виконання } \\
\text { працівниками } \\
\text { окремих видів } \\
\text { робіт } \\
\end{array}$ & $\begin{array}{l}\text { колектив працівників у процесі виробництва } \\
\text { переданих їм цінностей, та коли неможливо } \\
\text { розмежувати матеріальну відповідальність кожного } \\
\text { працівника й укласти } 3 \text { ним договір про повну } \\
\text { матеріальну відповідальність }\end{array}$ \\
\hline
\end{tabular}

Джерело: узагальнено авторами на основі [10]

Працівники, що несуть відповідальність за зберігання матеріальних цінностей зобов'язані укласти письмові угоди про повну матеріальну відповідальність. Письмові договори про повну матеріальну відповідальність може бути укладено 
підприємством, установою, організацією 3 працівниками (що досягли вісімнадцятирічного віку), які займають посади або виконують роботи, безпосередньо зв'язані із зберіганням, обробкою, продажем (відпуском), перевезенням або застосуванням у процесі виробництва переданих їм цінностей. Перелік таких посад і робіт, а також типовий договір про повну індивідуальну матеріальну відповідальність затверджуються в порядку, який визначається Кабінетом Міністрів України [10].

При настанні матеріальної відповідальності у наукових установах, важливою проблемою $є$ визначення розміру шкоди. Вважаємо, що основними факторами, що можуть впливати на вирішення даного питання можуть бути: розмір прямої шкоди, заподіяної працівником установи; характер шкоди та ситуації іiі настання; ступінь вини особи, що завдала шкоди та ії майновий стан; природа діяльності установи; вид матеріальної відповідальності, що буде застосовуватись.

Розрізняють наступні напрями відшкодування шкоди: добровільне відшкодування; стягнення коштів з винного працівника на основі наказу керівника; стягнення коштів через суд.

Обмеження розміру відрахувань із заробітної плати, установлене ст. 128 КЗпП: під час кожної виплати заробітної плати загальний розмір усіх відрахувань не може перевищувати 20\%. Тобто, якщо сума до стягнення перевищує допустиму межу, то таке стягнення необхідно погашати протягом кількох місяців [12].

Враховуючи вище викладене, під контролем за діяльністю матеріальновідповідальних осіб наукових установ, слід розуміти цілісний процес, який здійснюється керівництвом та працівниками установи, що направлений на виявлення відхилень та недоліків у роботі матеріально-відповідальних осіб та притягнення винних осіб до відповідальності. Такий різновид контролю може залежати від форми організації, службових та функціональних обов'язків працівників, що здійснюють даний контроль, місця контролю в системі управління установою, напрямів контрольної діяльності установи, тощо.

Вважаємо, що вдосконалення контролю за діяльністю матеріальновідповідальних осіб наукових установ можна досягти шляхом:

- запровадження в установі проведення інструктажу матеріальновідповідальних осіб, щодо їх прав та обов'язків та визначення даних позицій в посадових інструкціях;

- запровадження в установі аналітичних відомостей, де фіксувати інформацію про винних осіб, причини відхилень, дії або бездіяльність осіб, що призвели до відхилень;

- здійснення контрольних дій особами згідно їх посадових інструкцій;

- формування окремого підрозділу (відділу) внутрішньогосподарського контролю, який виконуватиме контрольні функції в т.ч. контролю за матеріальновідповідальними особами чи впровадження посади внутрішнього контролера;

- комп'ютеризації контролю, що вирішуватиме такі проблемні питання: додержання об'єктивності, строків проведення, точності результатів, зменшення величини витрат тощо;

- розробки та впровадження системи внутрішньої регламентації контролю наукової установи, де потрібно передбачити загальні питання контролю на рівні установи, більш чіткі положення внутрішнього контролю пов'язані із конкретними суб'єктами його здійснення, визначення прав та обов'язків осіб, що пов'язані із контрольною діяльністю. 
Висновки. Таким чином організація контролю в наукових установах відіграє важливе значення, адже його чітке налагодження на всіх етапах управління забезпечує безперервність діяльності, збереження майна, прийняття дієвих управлінських рішень та виявлення і використання внутрішніх резервів поліпшення діяльності а також запобігає перевитратам в діяльності зловживанням.

Дослідження літературних джерел, дає можливість стверджувати, що організація контролю за діяльністю матеріально-відповідальних осіб в наукових установах потребує вдосконалення. Це можуть бути заходи пов'язані з проведенням інструктажів матеріально-відповідальних осіб, веденням аналітичних відомостей, де фіксувати інформацію про винних осіб, причини відхилень, тощо, комп'ютеризації контролю, розробці та впровадженню системи внутрішньої регламентації контролю наукової установи, тощо. Запропоновані авторами напрями вдосконалення організації контролю за діяльністю матеріально-відповідальних осіб наукових установ, забезпечуватимуть інформаційні потреби власників та керівників та сприятимуть прийняттю ефективних управлінських рішень.

\section{Список використаних джерел}

1. Калетнік Г.М., Гунько І.В., Кірєєва Е.А. Практична реалізація державної політики у сфері вищої освіти та положень нового закону "Про вищу освіту" в концептуальних засадах підготовки фахівців на базі ННВК "Всеукраїнський науковонавчальний консорціум". Економіка. Фінанси. Менеджмент: актуальні питання науки і практики: всеукраӥнський науково-виробничий журнал. Вінниця, 2016. № 9 (13). C. 7-19.

2. Гуцаленко Л.В., Коцупатрий М.М., Марчук У.О. Внутрішньогосподарський контроль: навч. посіб. К.: “Центр учбової літератури”, 2014. 496 с.

3. Левенець М. М. Матеріально-правова відповідальність державних службовців: національний та зарубіжний досвід. Соціально-гуманітарний вісник. 2018. Вип. 24. С. 141-143.

4. Мацько М.А. Матеріальна відповідальність сторін трудового договору і майнова цивільно-правова відповідальність: науково-практичні підходи з огляду на захисну та виробничу функції трудового права. Вісник Львівського торговельноекономічного університету. Юридичні науки. 2017. Вип. 5. С. 243-256.

5. Костюченко О. Є. Правове регулювання матеріальної відповідальності роботодавця: сучасний стан та перспективи розвитку. Право та інновації. 2016. № 1. C. 81-88.

6. Державна служба статистики України: офіційний сайт. URL: http://www.ukrstat.gov.ua

7. Інститут продовольчих ресурсів: офіційний сайт. URL: http://iprkyiv.com/index.php/struktura

8. Методичні рекомендації 3 організації внутрішнього контролю розпорядниками бюджетних коштів у своїх закладах та у підвідомчих бюджетних установах: Наказ Міністерства фінансів України від 14.09.2012 № 995.

9. Мироненко В.П. Поняття матеріальної відповідальності працівників у трудовому праві. Юридична наука. 2012. № 1. С. 52-58.

10. Кодекс законів про працю України: Кодекс від 10.12.1971 № 322-VIII, в редакції від 11.10.2018. 
11. Лега О. В. Економіко-правові аспекти матеріальної відповідальності облікових працівників. Вісник ЖДТУ. 2010. № 3 (53). С.150-151.

12. Матеріальна відповідальність працівників: поняття та види. Інтерактивна бухгалтерія. 2017. №118. URL: http://www.interbuh.com.ua/ua/ documents/ oneanalytics/811

\section{References}

1. Kaletnik H.M., Hunko I.V. \& Kirieieva E.A. (2016). Praktychna realizatsiia derzhavnoi polityky u sferi vyshchoi osvity ta polozhen novoho zakonu "Pro vyshchu osvitu" v kontseptualnykh zasadakh pidhotovky fakhivtsiv na bazi NNVK "Vseukrainskyi naukovo-navchalnyi konsortsium" [Practical realization of public policy in the field of higher education and new law provisions "About higher education" in conceptual principles of preparation of specialists on a base ННВК the "Allukrainian науково-навчальний consortium"] Ekonomika. Finansy. Menedzhment: aktualni pytannia nauky i praktyky: vseukrainskyi naukovo-vyrobnychyi zhurnal - Economy. Finances. Management: pressing questions of science and practice : allukrainian scientific and production magazine. Vinnytsia, № 9 (13),7-19 [in Ukrainian].

2. Hutsalenko L. V., Kotsupatryi M.M. \& Marchuk U.O. (2014). Vnutrishnohospodarskyi kontrol: navch. posib. [Internal control: train aid]. K.: "Tsentr uchbovoi literatury", 496 [in Ukrainian].

3. Levenets M. M. (2018). Materialno-pravova vidpovidalnist derzhavnykh sluzhbovtsiv: natsionalnyi ta zarubizhnyi dosvid [Materially-legal responsibility of civil servants: national and foreign experience]. Sotsialno-humanitarnyi visnyk Socialhumanitarian announcer. Vyp. 24, 141-143 [in Ukrainian].

4. Matsko M. A. (2017). Materialna vidpovidalnist storin trudovoho dohovoru i mainova tsyvilno-pravova vidpovidalnist: naukovo-praktychni pidkhody $\mathrm{z}$ ohliadu na zakhysnu ta vyrobnychu funktsii trudovoho prava [Property accountability of parties of labour contract and property civil liability: research and practice approaches, taking into account the protective and productive functions of labour right] Visnyk Lvivskoho torhovelno-ekonomichnoho universytetu. Yurydychni nauky - Announcer of the Lviv trade and economic university. Legal sciences. Vyp. 5, 243-256 [in Ukrainian].

5. Kostiuchenko O. Ye. (2016). Pravove rehuliuvannia materialnoi vidpovidalnosti robotodavtsia: suchasnyi stan ta perspektyvy rozvytku [Legal adjusting of property accountability of employer : the modern state and prospects of development]. Pravo ta innovatsii - Right and innovations, № 1, 81-88 [in Ukrainian].

6. Derzhavna sluzhba statystyky Ukrainy: ofitsiinyi sait [Government service of statistics of Ukraine: official web-site]. URL: http://www.ukrstat.gov.ua [in Ukrainian].

7. Instytut prodovolchykh resursiv: ofitsiinyi sait [Institute of food resources : official web-site]. URL: http://iprkyiv.com/index.php/struktura [in Ukrainian].

8. Metodychni rekomendatsii z orhanizatsii vnutrishnoho kontroliu rozporiadnykamy biudzhetnykh koshtiv u svoikh zakladakh ta u pidvidomchykh biudzhetnykh ustanovakh [Methodical recommendations from organization of internal control by the managers of budgetary facilities in the establishments and in jurisdiction budgetary establishments]: Nakaz Ministerstva finansiv Ukrainy vid 14.09.2012 № 995 [in Ukrainian].

9. Myronenko V.P. (2012). Poniattia materialnoi vidpovidalnosti pratsivnykiv u trudovomu pravi [A concept of property accountability of workers is in a labour right]. Yurydychna nauka - Legal science, № 1, 52-58 [in Ukrainian]. 
10. Kodeks zakoniv pro pratsiu Ukrainy [There is a labour code Ukraine]: Kodeks vid 10.12.1971 № 322-VIII, v redaktsii vid 11.10.2018 [in Ukrainian].

11. Leha O. V. (2010). Ekonomiko-pravovi aspekty materialnoi vidpovidalnosti oblikovykh pratsivnykiv [The economic and legal aspects of the liability of accounting officers]. Visnyk ZhDTU - Journal of ZSTU, № 3 (53), 150-151 [in Ukrainian].

12. Materialna vidpovidalnist pratsivnykiv: poniattia ta vydy [Property accountability of workers: concept and kinds]. (2017). Interaktyvna bukhhalteriia Interactive book-keeping, №118. URL: http://www.interbuh.com.ua/ua/ documents/oneanalytics/811 [in Ukrainian].

\section{Інформація про авторів}

КОПИЛОВА Катерина В'ячеславівна - доктор сільськогосподарських наук, старший науковий співробітник, заступник директора 3 наукової та інноваційної роботи, Інститут продовольчих ресурсів НААН України (02002, м. Київ, вул. Свгена Сверстюка (Марини Раскової), 4A, e-mail: kopylket@ukr.net).

МУЛИК Ярославна Ігорівна - кандидат економічних наук, старший викладач кафедри аудиту та державного контролю, Вінницький національний аграрний університет (21008, м. Вінниця, вул. Сонячна, 3, e-mail: mulyk.yaroslavna@ ukr.net).

KOPYLOVA Ekaterina - Doctor of Agricultural Sciences, Senior Researcher, Deputy Director of the Scientific and Innovative Work of the Institute of Food Resources of the NASU (02002, Kyiv, Yevhen Sverstyuk Str. 4A e-mail:, kopylket@ukr.net

MULYK Yaroslavna - Candidate of Economic Sciences, Senior Lecturer of the Audit and State Control Department, Vinnytsia National Agrarian University (21008, Vinnytsia, 3, Sonyachna Str., e-mail: mulyk.yaroslavna@ukr.net).

КОПИЛОВА Екатерина Вячеславовна - доктор сельскохозяйственных наук, старший научный сотрудник, заместитель директора по научной и инновационной работе, Институт продовольственных ресурсов НААН Украины (02002, г. Киев, ул. Евгения Сверстюка (Марины Расковой), 4A, е - mail: kopylket@ukr.net).

МУЛЫК Ярославна Игоревна - кандидат экономических наук, старший преподаватель кафедры аудита и государственного контроля, Винницкий национальный аграрный университет (21008, г. Винница, ул. Солнечная, 3, e-mail: mulyk.yaroslavna@ukr.net). 